\title{
Pengaruh Atribut Perusahaan terhadap Keterlambatan Audit pada Perusahaan Consumer Goods dan Perusahaan Insurance yang Terdaftar di Bursa Efek Indonesia
}

\author{
Eva Marin Sambo \\ NunungPratiwi \\ STIEM Bongaya Makassar \\ coralie_ms@yahoo.co.id \\ (Diterima: 13-Februari-2020; dipublikasikan: 31-Juli-2020)
}

\begin{abstract}
This research aims to analyze and determine the effect of industry type and company age on audit delays in consumer goods companies and insurance companies listed in the Indonesia Stock Exchange. The phenomenon that has occurred in recent years is the Indonesian Capital Market has been late in reporting financial reports and audit reports. The research method used was quantitative research using multiple linear regression analysis. The research data used was secondary data in the form of financial reports and audit reports of public companies listed in the Indonesia Stock Exchange. The sample of this research were 48 companies in two years. This research used a classic assumption test with SPSS. The results of the research showed that partially the industry type and age of the company did not affect the audit delay.
\end{abstract}

Keywords: Type of Industry; Company Age; Audit Delay

\begin{abstract}
Abstrak
Penelitian ini bertujuan menganalisis dan mengetahui pengaruh jenis industri dan umur perusahaan terhadap keterlambatan audit pada perusahaan consumer goods dan perusahaan insurance yang terdaftar di Bursa Efek Indonesia.Fenomena yang terjadibeberapatahuninibahwadi Pasar Modal Indonesia terjadiketerlambatan perusahaan dalam melaporkan laporan keuangan dan laporan audit.Metode penelitian yang digunakan adalah penelitian kuantitatif dengan menggunakan analisis regresi linier berganda. Penelitian menggunakan data sekunder berupa laporan keuangan dan laporan audit perusahaan terbuka yang terdaftar di Bursa Efek Indonesia. Sampel penelitian ini sebanyak 48 perusahaan dalam dua tahun. Penelitian ini menggunakan uji asumsi klasik dengan alat bantu SPSS.Hasil penelitian menunjukkan bahwa secara parsial jenis industri dan umur perusahaan tidak berpengaruh terhadap keterlambatan audit.
\end{abstract}

Kata Kunci: Jenis Industri; Umur Perusahaan; Keterlambatan Audit 


\section{PENDAHULUAN}

Perkembangan pasar modal saat ini telah meningkat dengan sangat pesat dan tentunya di masa mendatang bisnis investasi ini akan menjadi sedemikian kompleks dengan tingkat persaingan yang sangat ketat, terutama dalam upaya penyediaan dan perolehan informasi dalam setiap pembuatan keputusan. Salah satu sumber informasi penting dalam bisnis investasi di pasar modal adalah laporan keuangan yang disediakan setiap perusahaan yanggo public.

Fenomena yang terjadi adalah Otoritas Jasa Keuangan (OJK) masih saja menemukan beberapa keterlambatan pelaporan keuangan yang dilakukan oleh beberapa perusahaan publik. Hingga bulan Desember 2014, OJK mencatat terdapat 30 sanksi peringatan tertulis dan 665 sanksi administrasi denda karena keterlambatan penyampaian laporan berkala dan laporan insidental dengan total nilai denda sebesar Rp 6,s549 miliar. Pada tangal 30 Mei 2013, sebanyak dua belas perusahaan belum menyampaikan laporan keuangan audi$\tan 2012$ sehingga dikenakan peringatan tertulis III serta tambahan denda sebesar Rp150 juta. Tahun 2012 tercatat sebanyak 54 perusahaan terlambat menyampaikan laporan keuangan auditan periode 2011. Informasi ini diperoleh dari berita harian ekonomi Mentro TV www.ekonomi.metrotvnews.com pada tanggal 7 Januari 2015.

Menurut IAI (2014) dalam PSAK (2015), tujuan dari laporan keuangan adalah untuk memberikan informasi mengenai posisi keuangan, kinerja keuangan, dan arus kas entitas yang bermanfaat bagi sebagian besar pengguna laporan keuangan dalam pembuatan keputusan ekonomik. Informasi yang terdapat dalam laporan keuangan perusahaan dapat bermanfaat apabila disajikan secara akurat dan tepat waktu pada saat yang dibutuhkan oleh para pengguna laporan keuangan seperti kreditor, investor, pemerintah, masyarakat, dan pihak-pihak lain sebagai dasar pengambilan keputusan.

Laporan keuangan berfungsi sebagai alat informasi yang menghubungkan perusahaan dengan pihak-pihak berkepentingan yang menunjukan kondisi kesehatan keuangan perusahaan dari kinerja perusahaan.Laporan keuangan pada dasarnya harus memenuhi karakteristik yang merupakan ciri khas informasi laporan keuangan yaitu dapat dipahami, relevan, materialitas,keandalan, penyajian jujur, substansi mengungguli bentuk, netralitas, pertimbangan sehat, kelengkapan, dan dapat dibandingkan (IAI, 2014).

Terdapat beberapa kendala untuk menghasilkan laporan keuangan yang memberikan informasi yang relevan, salah satunya adalah ketetapan waktu dalam penyampaian laporan keuangan yang dipublikasikan. Apabila laporan keuangan tidak disajikan tepat waktu, laporan keuangan tersebut akan kehilangan nilai informasi karena tidak tersedia saat pemakai laporan keuangan membutuhkan pertimbangan dalam pengambilan keputusan (IAI,2014).

Jika terdapat penundaan yang tidak semestinya dalam pelaporan, maka informasi yang dihasilkan akan kehilangan relevansinya (PSAK 2012 penyajian laporan keuangan paragraf 43). Relevan adalah sebagian dari karakteristik kualitatif laporan keuangan. Relevan artinya bahwa informasi tersebut dapat membantu para pengguna laporan keuangan dalam membuat keputusan ekonomi. Pembuatan keputusan ekonomi dilakukan dengan mengevaluasi peristiwa yang akan terjadi di masa lalu, saat sekarang, maupun masa yang akan datang. Salah satu indikator dari relevansi itu adalah ketepatwaktuan (timelines). (Kadir 2011).

Ketetapan waktu pelaporan keuangan diatur dalam Undang-Undang No.8 Tahun 1995, disebutkan bahwa semua perusahaan yang terdaftar di Pasar Modal wajib menyampaikan laporan keuangan secara berkala kepada Badan Pengawas Pasar Modal (Bapepam) atau sekarang dikenal Otoritas Jasa Keuangan (OJK) dan mengumumkan kepada masyarakat. Hal ini dilakukan OJK untuk melindungi para pemegang saham atau penanam modal, karena laporan keuangan yang disampaikan dapat saja berupa good news atau bad news. Pengumuman laba yang berisikan berita tidak baik maka pihak manajemen cenderung akan melaporkan laporan keuangannya tidak tepat waktu (Wulantoro, 2011).

Keterlambatan audit atau biasa yang disebut audit delay adalah lamanya waktu 
penyelesaian audit dihitung mulai dari tanggal diterbitkannya laporan audit (Dyer dan McHUgh 1975). Perbedaan waktu terjadi antara tanggal laporan keuangan dan penyelesaian penyusunan laporan keuangan, serta tanggal publikasi laporan keuangan karena laporan keuangan yang telah selesai disusun oleh perusahaan harus diaudit terlebih dahulu oleh akuntan publik sebelum dipublikasikan (Apriayanti dan Santoso, 2014).

Ada beberapa faktor yang dapat memengaruhi keterlambatan audit, salah satu yang paling penting untuk diperhatikan ialah atribut perusahaan (Apriyanti dan Santosa 2014). Definisi dari atribut dalam Kamus Besar Bahasa Indonesia adalah tanda kelengkapan. Atribut perusahaan ialah ciri-ciri yang dimiliki oleh perusahaan yang mencerminkan tentang perusahaan. Terdapat banyak atribut yang dimiliki oleh perusahaan untuk dapat mengenali suatu perusahaan, seperti ukuran perusahaan, jenis industri, umur perusahaan, dan subsidiari. Akan tetapi,dalam penelitian ini penulis hanya akan mengungkap tentang jenis industri dan umur perusahaan untuk diteliti. Penelitian ini akan membahas mengenai apakah jenis industri dan umur perusahaan berpengaruh terhadap keterlambatan audit? Dihipotesakan bahwa kedua atribut perusahaan ini memengaruhi keterlambatan audit.

Carslaw dan Kaplan (1991) mengemukakan bahwa klasifikasi industri dapat dibedakan menjadi dua kelompok yaitu perusahaan keuangan dan perusahaan non keuangan. Audit pada perusahaan non keuangan membutuhkan waktu relatif lama dibandingkan audit pada perusahaan non keuangan terkait dengan adanya audit pos persediaan yang terdapat pada perusahaan non keuangan. Pada klasifikasi perusahaan nonkeuangan, ada industri tertentu yang memiliki kompleksitas operasional yang cukup tinggi dibandingkan kelompok industri keuangan. Proses ini dapat menyebabkan keterlambatan audit pada perusahaan non keuangan. Dengan kata lain jenis industri dapat memengaruhi keterlambatan audit.

Berikut beberapa teori yang berhubungan dengan masalah yang akan dibahas dalam penelitian ini:
1. Keterlambatan Audit (Audit Delay)

Ketetapan waktu pelaporan keuangan merupakan elemen pokok bagi catatan laporan keuangan yang memadai. Ketetapan waktu mengimpliasikan bahwa laporan keuangan seharusnya disajikan pada suatu interval waktu untuk menjelaskan suatu perubahan dalam perusahaan yang mungkin memengaruhi pemakai informasi dalam membuat prediksi dan keputusan (Dyer dan McHUgh, 1975).Keterlambatan audit adalah rentang waktu antara tanggal tutup tahun buku perusahaan atau tanggal neraca hingga tanggal diterbitkannya laporan audit oleh Kantor Akuntan Publik yang mengaudit perusahaan tersebut (Ashton et al, 1987).

Rachmawati (2008) menyatakan audit delay adalah rentang waktu penyelesaian audit laporan keuangan tahunan yang diukur berdasarkan lamanya hari yang dibutuhkan untuk memperoleh laporan auditor independen atas audit laporan keuangan tahunan perusahaan, sejak tanggal tahun tutup buku perusahaan yaitu 31 Desember sampai tanggal tertera pada laporan auditor independen. Selisih jarak waktu antara berakhirnya tahun fiskal dengan tanggal diterbitkannya laporan audit inilah yang disebut audit delay.Begitupula yang dikemukakan oleh Saemargani dan Mustikawati (2015) bahwa keterlambatan audit atau audit delay adalah perbedaan waktu antara tanggal laporan keuangan dengan tanggal opini audit dalam laporan keuangan mengindikasikan tentang lamanya waktu penyelesaian audit yang dilakukan oleh auditor.

Audit delay juga didefinisikan sebagai jumlah hari dari tanggal tutup buku tahun perusahaan 31 Desember sampai tanggal ditandatanganinya laporan audit (Robbitasari, 2013). Panjang pendeknya audit delay dipengaruhi oleh kerumitan proses audit. Tingkat kerumitan yang tinggi mengakibatkan auditor memerlukan jumlah hari yang lebih banyak untuk mengaudit perusahaan induk beserta anak perusahaannya (Che-Ahmad dan Abidin, 2008).Indikator dari keterlambatan audit adalah tanggal laporan keuangan dan tanggal laporan audit (Apriyanti dan Santosa, 2014). Telah dikemukakan dalam PSAK No.8 
(IAI,2010) tanggal laporan keuangan diotorisasi untuk terbit adalah tanggal ketika laporan keuangan sudah final, yang berarti tidak ada lagi koreksi atau penyesuaian setelah tanggal tersebut. Laporan keuangan auditan tanggal ini adalah tanggal laporan auditor, sementara untuk laporan keuangan yang tidak diaudit, tanggal ini adalah tanggal ketika laporan keuangan selesai disusun oleh manajemen.

\section{Atribut Perusahaan}

Kamus Besar Bahasa Indonesia mengartikan atribut ialah tanda kelengkapan. Atribut perusahaan adalah ciri-ciri yang dimiliki oleh perusahaan yang mencerminkan tentang perusahaan. Terdapat banyak atribut yang dimiliki oleh perusahaan, seperti: 1) Jenis Industri. MenurutBadanPusatStatistik (2008), industri mencakup semua usaha dan kegiatan di bidang ekonomi bersifat produktif.Adapun pengertian industri menurutHansiSiahaanadalahbagiandari proses yang mengelolabahanmentahmenjadibahanbakuataubahanbak umenjadibarangjadisehinggamenjadibarang yang bernilaibagimasyarakat.

Ashton et al. (1987),membagi jenis industri menjadi dua golongan besar, yaitu industri sektor keuangan dan industri non keuangan. Industri sektor keuangan adalah industri yang memberikan jasa keuangan dan terkait dengan uang dan investasi. Industri sektor keuangan juga digunakan untuk merujuk pada organisasi yang menangani pengelolaan dana, sedangkan jenis industri non keuangan adalah semua jenis industri yang tidak termasuk dalam industri sektor keuangan.

Atribut selanjutnya yang dimiliki perusahaan: 2) Umur Perusahaan. Nugroho dalam Kusnia (2013) mendefinisikan umur perusahaan sebagai berikut: "Umur perusahaan merupakan awal perusahaan melakukan aktivitas operasioanal hingga dapat mempertahankan going concern perusahaan tersebut atau mempertahankan eksistensinya dalam dunia bisnis". Umur perusahaan adalah umur perusahaan yang dihitung sejak perusahaan tersebut telah terdaftar di bursa efek indonesia sampai dengan dilakukannya penelitian (Togasima dan Christiawan 2014).
Perusahaan yang sudah lama berdiri biasanya mempunyai sistem yang sudah lebih tertata, termasuk prosedur internal kontrol yang sudah semakin teruji sehingga dapat mengurangi terjadinya kesalahan dalam penyajian laporan keuangan. Olehnya itu, perusahaan yang telah lama berdiri memiliki kecenderungan untuk tidak mengalami penundaan laporan keuangan (Apriyanti dan Santosa 2014).Semakin lama umur suatu perusahaan maka jangka waktu penyelesaian audit hingga laporan diterbitkan akan semakin cepat demikian pula sebaliknya (Owusu dan Ansah 2000).Adapun lama umur perusahaan dihitung sejak perusahaan didirikan sampai dilakukannya penelitian ini.

\section{METODE PENELITIAN}

Populasi yang akan diamati dalam penelitian ini adalah seluruh perusahaanConsumer Goods dan perusahaan Insurance yang terdaftar di Bursa Efek Indonesia yag berjumlah 26 perusahaan.Teknik pengambilan sampel menggunakan metode purposive sampling yaitu teknik pengambilan sampel tidak acak yang informasinya diperoleh dengan kriteria tertentu (Sugiyono, 2009:216). Kriteria tersebut adalah: Berdasarkankriteria yang telahditetapkanmakaperusahaan yang memenuhi syarat dalam penelitian ini sebanyak 24 perusahaan, selama 2 tahun sehingga jumlah observasi sebanyak 48 sampel.

Jenis data penelitian ini adalah data kuantitatif yang bersifat deskriptif yang menjabarkan data laporan keuangan perusahaanconsumer goods dan perusahaan insurance yang terdaftar di Bursa Efek Indonesia.Data yang digunakan yaitu data sekunder yang diperoleh dari situs Bursa Efek Indonesia www.idx.co.id dan dari situs Indonesian Capital Market Directory (ICMD).

Jenis industri terbagi atas menjadi dua karakteristik yaitu industri non keuangan dan industri keuangan. Menurut Iskandar, Trisnawati (2010) industri keuangan cenderung memiliki aset berupa aset moneter yang lebih mudah diukur. Sebaliknya, kebanyakan aset dari industri non keuangan membutuhkan banyak aset berupa fisik seperti mesin dan peralatan lainya untuk melangsungkan proses 
bisnisnya. Industri keuangan memiliki sistem informasi akuntansi yang lebih tersentralisasi dan terotomatisasi dibandingkan dengan industri non keuangan.Umur perusahaan merupakan awal perusahaan melakukan aktivitas operasionalnya hingga dapat mempertahankan going concern perusahaan tersebut atau mempertahankan eksistensinya dalam dunia bisnis. Umur perusahaan dalam penelitian ini menggunakan umur perusahaan dari tanggal perusahaan didirikan sampai dengan dilakukan penelitian. Keterlambatan audit adalah rentang waktu antara tanggal tutup tahun buku perusahaan atau tanggal neraca hingga tang- gal diterbitkannya laporan audit oleh Kantor Akuntan Publik yang mengaudit perusahaan tersebut (Ashton et al, 1987).Keterlambatan audit atau audit delay dalam penelitian ini diukur berdasarkan rentang waktu penyelesaian pelaksanaan audit laporan keuangan tahunan, yaitu dari lamanya hari yang dibutuhkan untuk memperoleh laporan auditor independen atas laporan keuangan tahunan perusahaan. Dihitung sejak tanggal tutup buku perusahaan yaitu per 31 Desember sampai tanggal yang tertera pada laporan auditor independen.Berikut tabel dari definisi operasional dan pengukuran dalam penelitianini.

Tabel 1 DefinisiOperasionaldanPengukuran

\begin{tabular}{llllc}
\hline Variabel penelitian & \multicolumn{1}{c}{ Indikator } & \multicolumn{1}{c}{ Skala } & \multicolumn{2}{c}{ Sumber data } \\
\hline Keterlambatan Audit & $\begin{array}{l}\text { Jumlah hari antara tanggal laporan keuan- } \\
\text { gan per 31 Desember sampai tanggal lapo- } \\
\text { ran audit. }\end{array}$ & Interval & $\begin{array}{l}\text { Sekunder } \\
\text { auditor) }\end{array}$ & \\
& $\begin{array}{l}\text { Industri non keuangan: kompleksitas asset } \\
\text { (1), industri keuangan: asset moneter (0). }\end{array}$ & Nominal & $\begin{array}{l}\text { Sekunder (dari Laporan } \\
\text { keuangan) }\end{array}$ & \\
\hline Jenis Industri & $\begin{array}{l}\text { Sejak tahun perusahaandidirikan sampai } \\
\text { dengan tahun penelitian }\end{array}$ & Interval & $\begin{array}{l}\text { Sekunder (dari laporan } \\
\text { keuangan) }\end{array}$ & \\
\hline Umur Perusahaan & & & langan \\
\hline
\end{tabular}

Selanjutnya, metode analisis data dilakukan dengan cara berikut:

\section{Uji Multikolinearitas}

Uji multikolonieritas bertujuan untuk menguji apakah model regresi ditemukan adanya korelasi antar variabel bebas (independen). Model regresi yang baik seharusnya tidak terjadi korelasi di antara variabel independen. Mendeteksi ada atau tidaknya multikolonieritas dalam sebuah model regresi adalah:Nilai R2 yang dihasilkan oleh suatu estimasi model regresi empiris sangat tinggi namun secara individual variabel-variabel independen banyak yang tidak signifikan yang kemudian akan mempengaruhi variabel dependen.Multikolonieritas dapat dilihat dari nilai tolerance dan lawannya,variance inflation factor(VIF). Nilai tolerance yang rendah sama dengan nilai VIF yang tinggi karena keduanya berhubungan terbalik.Nilai cut-off yang umum dipakai untuk menunjukkan adanya multikolinearitas adalah nilai tolerance 0 dan nilai VIF 0 . Jika nilai 0 lebih kecil dari 0,10 berarti terdapat korelasi antar variabel independen yang nilainya lebih dari $95 \%$.
Indikator adanya multikolinearitas yaitu jika nilai VIF lebih dari 10.

2. Uji Normalitas

Uji normalitas bertujuan untuk menguji apakah dalam sebuah model regresi, variabel pengganggu atau residual mempunyai distribusi normal atau tidak. Uji normalitas menggunakan uji Kolmogorov-Smirnov (K-S). Dasar pengembalian keputusan dalam uji K-S adalah sebagai berikut:Apabila nilai signifikansi atau nilai probabilitas $>0,05$ atau 5 persen maka data terdistribusisecara normaldanapabilanilaisignifikansi atau nilai probabilitas < 0,05 atau 5 persen maka data tidak terdistribusi normal.

3. Uji Heteroskedastisitas

Uji heteroskedasitas bertujuan menguji apakah dalam model regresi terjadi ketidaksamaan varians dan residual satu pengamatan ke pengamatan yang lain. Jika varians dari residual satu ke pengamatan yang lain tetap, maka disebut homoskedasitas dan jika berbeda disebut heteroskedasitas. Digunakan uji heteroskedasitas menggunakan uji glejser dalam penelitian ini, untuk mengetahui tidak 
adanya heteroskedasitas ditunjukan dengan tidak ada satupun variabel independen yang signifikan secara statistik memengaruhi variabel dependen nilai Absolut Residual (AbsRes). Hal ini terlihat dari probabilitas signifikansinya di atas tingkat kepercayaan 5 persen.

Analisis inferensial yang digunakan dalam penelitian ini adalah analisis regresi berganda (multiple regression).Analisis regresi berganda digunakan mengingat variabel independen lebih dari satu. Pengujian ini berguna untuk mengetahui pengaruh variabel independen (jenis industri dan umur perusahaan) terhadap variabel dependen (keterlambatan audit atau audit delay). Persamaananalisisbergandaadalah:

$$
\mathrm{Y}=\mathrm{a}+\mathrm{b} 1 \mathrm{X} 1+\mathrm{b} 2 \mathrm{X} 2+\varepsilon
$$

Keterangan:

$$
\begin{array}{ll}
\mathrm{Y} & : \text { Keterlambatan audit } \\
\mathrm{a} & : \text { Konstanta } \\
\mathrm{b} 1, \mathrm{~b} 2 & : \text { Koefisiensi regresi masing-masing } \\
& \text { variabel X } \\
\mathrm{X} 1 & : \text { Jenis Industri } \\
\mathrm{X} 2 \quad & \text { : Umur Perusahaan } \\
& : \text { Error }
\end{array}
$$

\section{UjiHipotesis}

Alat uji yang digunakan untukmengujihubunganantarvariabeltersebutadalahuji $\mathrm{t}$ dankoefisiendeterminasi $\left(\mathrm{R}^{2}\right)$

1. Uji hipotesis parsial ( Uji t)

Uji statistik $t$ digunakan untuk mengetahui seberapa jauh pengaruh satu variabel independen secara individual dalam menerangkan variasi variabel dependen (Ghozali, 2013: 98). Pernyataan Hipotesis :

1. $H_{01}: B_{1} \geq 0$ : Jenis industri tidak berpengaruh terhadap keterlambatan audit.

$$
\begin{aligned}
\mathrm{H}_{a 1}: \mathrm{B}_{1}<0: & \text { Jenis industri berpengaruh } \\
& \text { terhadap keterlambatan } \\
& \text { audit. }
\end{aligned}
$$

$2 . \mathrm{H}_{02}: \mathrm{B}_{2} \geq 0$ : Umur perusahaan tidak berpengaruh terhadap keterlambatan audit.

$\mathrm{H}_{02}: \mathrm{B}_{2}<0$ : Umur perusahaan berpengaruh terhadap keterlambatan audit.

Kriteria pengujian dua pihak :

Jika $t_{\text {hit }}>\mathrm{F}_{t a b}$ : Maka Ha diterimadan Ho ditolak.

2. Koefesien determinasi ( $R^{2}$ )

Menurut Ghozali (2013:87) koefisien determinasi bertujuan untuk mengukur seberapa jauh kemampuan model dapat menjelaskan variasi variabel dependen. Dalam pengujian hipotesis koefisien determinasi dilihat dari besarnya niali R Square $\left({ }^{R^{2}}\right)$, untuk mengetahui seberapa jauh variabel bebas "jenis industri dan umur perusahaan terhadap keterlambatan audit". Nilai $\left({ }^{R^{2}}\right)$ mempunyai interval antara 0

\begin{tabular}{|c|c|c|c|c|c|c|c|c|}
\hline \multicolumn{9}{|c|}{ Coefficients $^{\mathrm{a}}$} \\
\hline \multirow[t]{2}{*}{ Model } & & \multicolumn{2}{|c|}{$\begin{array}{l}\text { Unstandardized Coeffi- } \\
\text { cients }\end{array}$} & \multirow{2}{*}{$\begin{array}{c}\begin{array}{l}\text { Standardized Coef- } \\
\text { ficients }\end{array} \\
\text { Beta }\end{array}$} & \multirow[t]{2}{*}{$\mathrm{T}$} & \multirow[t]{2}{*}{ Sig. } & \multicolumn{2}{|c|}{ Collinearity Statistics } \\
\hline & & $\mathrm{B}$ & Std. Error & & & & Tolerance & $\mathrm{VIF}$ \\
\hline \multirow{3}{*}{1} & (Constant) & 85.532 & 5.424 & & 15.768 & .000 & & \\
\hline & JENIS INDUSTRI & 6.751 & 4.076 & .234 & 1.656 & .105 & .992 & 1.009 \\
\hline & $\begin{array}{l}\text { UMUR PERUSA- } \\
\text { HAAN }\end{array}$ & -.351 & .232 & -.214 & -1.513 & .137 & .992 & 1.009 \\
\hline
\end{tabular}
sampai $1\left(0 \leq{ }^{R^{2}} \leq 1\right)$. Jika nilai ${ }^{2}$ bernilai besar (mendekati 1) berarti variabel bebas dapat memberikan hampir semua informasi yang dibutuhkan untuk memprediksi variabel dependen. Sedangkan jika $R^{2}$ bernilai kecil berarti kemampuan variabel bebas dalam menjelaskan variabeldependensangatterbatas.

\section{HASIL DAN PEMBAHASAN}

\section{HasilUjiMultikolinearitas}

Tabel 2 Hasil Uji Multikolinearitas

a. Dependent Variable: KETERLAMBATAN AUDIT 
Berdasarkan table 2, diketahui bahwa nilai tolerance variabel jenis industri dan umur perusahaan yaitu masing-masing sebesar 0,992 dan 0.992 lebih besar dari 0,10. Sementara nilai VIF variabel jenis industri dan umur perusahaan yaitu masing-masing sebesar 1,009 dan 1,009 lebih kecil dari 10,00, sehingga dapat disimpulkan tidak terjadi multikolonieritas.

\section{Hasil Uji Normalitas}

Tabel 3 Hasil Uji Normalitas

One-Sample Kolmogorov-Smirnov Test

\begin{tabular}{llr}
\hline & & $\begin{array}{c}\text { Unstandardized } \\
\text { Residual }\end{array}$ \\
\hline $\mathrm{N}$ & Mean & 48 \\
Normal Parameters & $0 \mathrm{E}-7$ \\
& Std. Deviation & 13.71075086 \\
& Absolute & .116 \\
Most Extreme Differences & Positive & .116 \\
& Negative & -.109 \\
Kolmogorov-Smirnov Z & & .801 \\
Asymp. Sig. (2-tailed) & .543 \\
\hline a. Test distribution is Normal. \\
b. Calculated from data.
\end{tabular}

Berdasarkan output spss pada tabel 3, diketahui bahwa nilai signifikansi sebesar 0,543, nilai ini lebih besar dari 0,05 , sehingga dapat disimpulkan bahwa data yang diuji berdistribusi normal. Hal ini menunjukkan bahwa model tersebut memenuhi syarat asumsi normalitas. Dengan demikian, pegujian regresi untuk pengaruh jenis industri dan umur perusahaan terhadap keterlambatan audit dapat dilanjutkan.

\section{Hasil Uji Heteroskedastisitas}

Tabel 4 Hasil Uji Heteroskedastisitas

Coefficients $^{\mathrm{a}}$

\begin{tabular}{|c|c|c|c|c|c|c|}
\hline \multirow{2}{*}{\multicolumn{2}{|c|}{ Model }} & \multicolumn{2}{|c|}{$\begin{array}{l}\text { Unstandardized } \\
\text { Coefficients }\end{array}$} & \multirow{2}{*}{$\begin{array}{c}\text { Stan- } \\
\text { dardized } \\
\text { Coeffi- } \\
\text { cients } \\
\text { Beta }\end{array}$} & \multirow[t]{2}{*}{$\mathrm{t}$} & \multirow[t]{2}{*}{ Sig. } \\
\hline & & B & $\begin{array}{l}\text { Std. } \\
\text { Error }\end{array}$ & & & \\
\hline \multirow{3}{*}{1} & (Constant) & 11.229 & 3.940 & & 2.850 & .007 \\
\hline & $\begin{array}{l}\text { JENIS IN- } \\
\text { DUSTRI }\end{array}$ & -1.701 & 2.961 & -.086 & -.574 & .568 \\
\hline & $\begin{array}{l}\text { UMUR PE- } \\
\text { RUSAHAAN }\end{array}$ & -.055 & .169 & -.049 & -.328 & .745 \\
\hline
\end{tabular}

Berdasarkan output spsspada tabel 4 diketahui bahwa:

1) Nilai signifikansi untuk variabel jenis industri sebesar 0.568 lebih besar dari 0.05 , artinya tidak terjadi heteroskedastisitas pada variabel jenis industri.

2) Nilai signifikansi untuk variabel umur perusahaan sebesar 0.745 lebih besar dari 0.05 , artinya tidak terjadi heteroskedastisitas pada variabel umur perusahaan.

\section{Analisis Data}

Analisis inferensial yang digunakan dalam penelitian ini adalah analisis regresi berganda (multiple regression). Adapun hasil dari analisis regresi berganda yaitu:

\begin{tabular}{|c|c|c|c|c|c|}
\hline \multicolumn{6}{|l|}{ Tabel 5 H } \\
\hline \multicolumn{6}{|l|}{ Coefficients ${ }^{\mathrm{a}}$} \\
\hline \multirow[t]{2}{*}{ Iodel } & \multicolumn{2}{|c|}{$\begin{array}{l}\text { Unstandardized } \\
\text { Coefficients }\end{array}$} & $\begin{array}{l}\text { Standard- } \\
\text { ized Co- } \\
\text { efficients }\end{array}$ & $\mathrm{t}$ & Sig. \\
\hline & $\mathrm{B}$ & Std. Error & Beta & & \\
\hline (Constant) & 85.532 & 5.424 & & $\begin{array}{r}15.76 \\
8\end{array}$ & .000 \\
\hline $\begin{array}{l}\text { JENIS IN- } \\
\text { DUSTRI }\end{array}$ & 6.751 & 4.076 & .234 & 1.656 & .105 \\
\hline $\begin{array}{l}\text { UMUR } \\
\text { PERUSA- } \\
\text { HAAN }\end{array}$ & -.351 & .232 & -.214 & -1.513 & .137 \\
\hline
\end{tabular}

Berdasarkan Tabel 5, diperoleh persamaan regresi berganda sebagai berikut:

$\mathrm{Y}=85,532-6,751 \mathrm{X} 1-0,351 \mathrm{X} 2$

$\mathrm{Y}=$ Keterlambatan audit

$\mathrm{X} 1=$ Jenis industri

$\mathrm{X} 2$ = Umur perusahaan

Persamaan regresi tersebut mempunyai makna sebagai berikut:

1) Konstanta $=85,532$

Jika variabel keterlambatan audit sebesat 85,532 hari maka variabel jenis industri dan umur perusahaan dianggap sama dengan nol.

2) Jenis industri $=6,751$

Koefisien regresi untuk variabel jenis industri sebesar 6,751, artinya bahwa setiap perubahan satu satuan variabel jenis industri maka keterlamabatan audit akan men- 
gakibatkan kenaikan sebesar 6,751 dengan asumsi jenis industri tetap.

3) Umur perusahaan $=-0,351$

Nilai koefisien regresi variabel umur perusahaan sebesar -0,351. Hal ini menunjukkan bahwa setiap peningkatan satu satuan umur perusahaan akan mengakibatkan kenaikan keterlambatan audit sebesar -0,351 dengan asumsi umur perusahaan tetap.

\section{HasilPengujianHipotesis}

\section{Uji Hipotesis Parsial (Uji t)}

\begin{tabular}{|c|c|c|c|c|c|}
\hline \multirow{4}{*}{$\frac{\text { Coefficients }^{\mathrm{a}}}{\text { Model }}$} & \multicolumn{5}{|c|}{ Tabel 6 Hasil Uji Parsial } \\
\hline & & & & & \\
\hline & \multicolumn{2}{|c|}{$\begin{array}{l}\text { Unstandardized } \\
\text { Coefficients }\end{array}$} & \multirow{2}{*}{$\begin{array}{c}\text { Stan- } \\
\text { dardized } \\
\text { Coeffi- } \\
\text { cients } \\
\text { Beta }\end{array}$} & \multirow[t]{2}{*}{$\mathrm{t}$} & \multirow[t]{2}{*}{ Sig. } \\
\hline & $\mathrm{B}$ & Std. Error & & & \\
\hline (Constant) & 85.532 & 5.424 & & 15.768 & .000 \\
\hline $\begin{array}{l}\text { JENIS } \\
\text { INDUS- } \\
1 \text { TRI }\end{array}$ & 6.751 & 4.076 & .234 & 1.656 & .105 \\
\hline $\begin{array}{l}\text { UMUR } \\
\text { PERUSA- } \\
\text { HAAN }\end{array}$ & -.351 & .232 & -.214 & -1.513 & .137 \\
\hline
\end{tabular}

\section{Hasil Uji Hipotesis Parsial :Pengaruh Jenis Industri Terhadap Keterlambatan Audit}

Berdasarkan hasil Uji Hipotesis Parsial (uji t) pada tabel 5 untuk variabel jenis industri yaitu diperoleh nilai ${ }^{t_{\text {hit }}}$ sebesar 1,656 dan nilai ${ }^{t_{\text {tab }}}$ dengan $\mathrm{a}=0.05$ dan derajat bebas $=48-1-1=46$ untuk pengujian dua pihak adalah 2,0129. Oleh karena itu ${ }^{t_{\text {hit }}}$ untuk koefisien variabel jenis industri 1.656 lebih kecil dari ${ }^{t_{\text {tab }}}$ sebesar 2.0129 maka ${ }^{H_{a 2}}$ ditolak dan $\mathrm{H}_{02}$ diterima, artinya jenis industri tidak berpengaruh terhadap keterlambatan audit.Hasil tersebut disebabkan oleh ada beberapa perusahaan jenis industry keuangandalam penelitian ini mempunyai jangka waktu yang lama dalam pelaporan audit dan ada beberapa perusahaan jenis industri non keuangan yang mempunyai jangka waktu yang singkat dalam pelaporan auditnya.
Hasil Uji Hipotesis Parsial : PengaruhUmur Perusahaan Terhadap Keterlambatan Audit

Berdasarkan hasil Uji Hipotesis Parsial (uji t) pada tabel 5 untuk variabel umur perusahaan yaitu diperoleh nilai $\mathbf{t}_{\text {hit }}$ sebesar 1,513 dan nilai ${ }^{t_{\text {tab }}}$ dengan $a=0.05$ dan derajat bebas $=48-1-1=46$ untuk pengujian dua pihak adalah 2,0129 (lampiran II).

Oleh karena itu ${ }^{t_{\text {hit }}}$ untuk koefisien variabel umur perusahaan -1,513 lebih kecil dari $t_{\text {tab }}$ sebesar 2.0129 maka ${ }^{\mathrm{H}_{\mathrm{a}}}$ ditolak dan $\mathrm{H}_{03}$ diterima, artinya umur perusahaantidak berpengaruh terhadap keterlambatan audit.Hasil tersebutdisebabkankarenaadabeberapaperusahaan yang telah lama berdiri $(21,22,25,26)$, namun mempunyai jangka waktu yang lama dalam pelaporan audit di bandingkan dengan jangka waktu pelaporan audit tahun sebelumnya. Berikut beberapa perusahaan tersebut:

\section{HasilUjiDeterminasi ${ }^{\left(R^{2}\right)}$}

\section{Tabel 7 Hasil Uji Determinasi}

Model Summary

\begin{tabular}{|c|c|c|c|c|}
\hline Model & $\mathrm{R}$ & R Square & $\begin{array}{l}\text { Adjusted R } \\
\text { Square }\end{array}$ & $\begin{array}{l}\text { Std. Error of } \\
\text { the Estimate }\end{array}$ \\
\hline 1 & $.331^{\mathrm{a}}$ & .110 & .070 & 14.012 \\
\hline
\end{tabular}

Berdasarkan table 7, diketahui bahwa nilai R Square sebesar 0,11 , hal ini berarti $11 \%$ variasi dari variabel dependen (keterlambatan audit) dapat dijelaskan oleh variasi variabel independen (jenis industri dan umur perusahaan). Sedangkan sisanya (100\% $11 \%=89 \%$ ) dijelaskan oleh variabel diluar penelitian ini seperti kualitas audit, ukuran perusahaan, profitabilitas, solvabilitas dan opini audit.

\section{KESIMPULAN}

Berdasarkan hasil analisis dan pembahasan yang telah dijelaskan, maka kesimpulan 
dari penelitian ini adalah:Jenis industri tidak berpengaruh terhadap keterlambatan audit. Artinya, perusahaan jenis industri apapun tidak memengaruhi cepat atau lambatnya keterlambatan audit pada perusahaan consumer goods dan perusahaan insurance yang terdaftar di Bursa Efek Indonesia. Selain itu, dilihat dari umur perusahan, hasil penelitian inimenunjukkan umur perusahaan tidak berpengaruh terhadap keterlambatan audit. Artinya, perusahaan yang telah lama berdiri dan perusahaan yang baru didirikan tidak memengaruhi cepat atau lambatnya keterlambatan audit pada perusahaan consumer goods dan perusahaan insurance yang terdaftar di Bursa Efek Indonesia.

Di masa mendatang, hasil penelitian ini dapat memberikan informasi dan bermanfaatsecara umum bagi perusahaan-perusahaan yang telah terdaftar atau perusahaan yang mau mendaftarkan perusahaannya dipasar modal bahwa perusahaan sebaiknya mengevaluasi kinerja perusahaan secara berkala agar dapat mengendalikan faktor-faktor dominan yang dapat memengaruhi jangka waktu penyelesaian audit. Selain itu, perusahaan diharapkan dapat memberikan data yang diperlukan selama proses pemeriksaan laporan keuangan sehingga laporan keuangan dapat dipublikasikan lebih awal. Hasil penelitian ini juga diharapkan dapat memberikan masukan kepada peneliti selanjutnya sebaiknya menambah variabel independen lain yang belum digunakan dalam penelitian ini serta menambah periode penelitian.

\section{DAFTAR PUSTAKA}

Agoes, Sukrisno. 2014. Auditing: Petunjuk Praktis Pemeriksaan Akuntan oleh Akuntan Public. Salemba Empat: Jakarta Selatan.

Che, Ahmad A.\& Abidin S. 2008.Audit Delay Of Listed Companies: A Case Of Malaysia International Journal Business Research, 4 (1).

Apriayanti, Setyarini Santosa. 2014. Pengaruh Atribut Peerusahaan dan Faktor Audit Terhadap Keterlambatan Audit pada Perusahaan yang Terdaftar di Bursa Efek Malaysia. Jurnal Akuntansi dan
Keuangan. 16(2): 74-87.

Ashton, R. H., Willingham, J. J., \& Elliott, R. K. 1987. An Emprical Analysis of Audit Delay. Journal of Accounting Research. 25(2).

Chandra, Hesti. 2011."Analisis Faktor-Faktor Yang Mempengaruhi Audit Delay Terhadap Jangka Waktu Penyelesaian Audit yang Terdaftar Di BEI Tahun 20082010". Skripsi. Semarang : Universitas Diponegoro.

Carslaw, C. A. P. N. \& Kaplan, S. E. 1991. An Examination of Audit Delay: Further Evidence from New Zealand. Accounting and Business Research. 22 (85):21-32.

Togasima, Cristian Noverta dan Yulius Jogi Christiwan. 2014. Analisis FaktorFaktor yang Mempengaruhi Audit Report Lag pada Perusahan yang Terdaftar di Bursa Efek Indonesia pada Tahun 2012. Jurnal Business Accounting Review.2(2):151-159.

Dyer, J.C. \& McHugh, A.L. 1975. The Timeliness of the Australian Annual Report. Journal of Accounting Research. 13 (3):2014-219.

Ghozali, Imam. 2006. Aplikasi Analisis Multivariate dengan Program SPSS, Edisi Keempat. Universitas Diponegoro: Semarang.

2009. "Aplikasi Analisis Multivariate dengan Program IBM SPSS 16”. Badan Penerbit Universitas Diponegoro: Semarang. 2011."Aplikasi Analisis Multivariate dengan Program SPSS 19 ( edisi kelima)". Badan Penerbit Universitas Diponegoro: Semarang.

Ikatan Akuntansi Indonesia. 2014. Standar Akuntansi keuangan, Salemba Empat: Jakarta.

2012. Standar Akuntansi keuangan, Salemba Empat: Jakarta.

2010. Standar

Akuntansi keuangan, Salemba Empat: Jakarta. 
111 AKUNSIKA, Vol 1, No 2, Juli 2020, hal 1 - 10

Iskandar, Meylisa Januar dan Trisnawati Estralita. 2010. Faktor-Faktor yang Mempengaruhi Audit Report Lag Ppada Perusahaan yang Terdaftar di Bursa Efek Indonesia. Jurnal Bisnis Dan Akuntasni. 12(3). 175-186.

Jumratul, Haryani dan I Dewa Nyoman Wiratmaja. 2014. Pengaruh Ukuran Perusahaan, Komite Audit, Penerapan International Financial Reporting Standars dan Kepemilikan Publik Pada Audit Delay. E-Jurnl Akuntansi Universitas Udayana. 6(1): 63-78.

Kadir, A. 2011. Faktor-Faktor yang Berpengaruh Terhadap Ketetapan Waktu Pelaporan Keuangan: Studi Empiris pada Perusahaan Manufaktur di Bursa Efek Jakarta. Jurnal Manajemen Dan Akuntansi.12(1).

Kartika, Andi. 2011. Faktor-Faktor yang Mempengaruhi Audit Delay pada Perusahaan Manufaktur yang Terdaftar di BEI).Jurnal Dinamika Keuangan dan Perbankan. Vol. 3. No. 2.

Kusnia, G. 2013.“Pengaruh Umur Perusahaan, Ukuran Perusahaan, dan Leverage Terhadap Intellectual Capital Disclosure". Skripsi. Bandung: Fakultas Ekonomi. Universitas Pasundan.

Owusu-Ansah, S. 2000. Timeliness of Corporate Financial Reporting in Emerging Capital Market: Emprical Evidence from the Zimbabwe Stock Exchange. Forthcoming in Accounting \& Business Research. 30(3).

Randal J. Elder, Mark S. Beasley, Alvin A. Arens, Amir Abadi Jusuf, 2011. Jasa Audit dan Assurance. Salemba Empat: Jakarta Selatan.

Riyani, Kusumawati. 2013. "Analisis FaktorFaktorang Mempengaruhi Audit Delay pada Emiten Perbankan yang Terdaftar Di BEI'. Skripsi. Depok: Fakultas Ekonomi Universitas Gunadarma.

Robbitasari, Ainurrizky Putri dan I Dea Nyoman Wiratmaja. 2013. Pengaruh Opini Audit Going Concern, Kepemilikan Institusional dan Audit Delay pada Voluntary Auditor Switching. E-Jurnal Akuntansi Universitas Udayana. 5(3): 652-
665.

Saemargani, Fitria Ingga dan Rr. Indah Mustikawati, M.Si., Ak. 2015. Pengaruh Ukuran Perusahaan, Profitabilitas, Sovabilitas, Ukuran Kap. dan Opini Auditor Terhadap Audit Delay. Jurnal Nominal.4(2):1-15.

Sepriana, Ira. 2010. Analisis Faktor-faktor yang Berpengaruh Terhadap Ketepatan Waktu Pelaporan Keuangan Perusahaan BUMN di Indonesia. Jurnal Maksi. 10 (1). $97-117$

Sugiyono. 2013. Metode Penelitian Pendidikan.Bandung: Alfabeta. 2009. Metode Penelitian Kuantitatif.Bandung: Alfabeta.

Theodorus, M. Tuanakota. 2015. Audit Kontemporer. Jakarta: Salemba Empat

Wiguna, Karina Rahayu. 2012. "Pengaruh Tenure Audit Terhadap Audit Report Lag dengan Spesialisasi Industri Auditor Sebagai Variabel Pemoderasi: Studi pada Bank Umum Konvensional di Indonesia Tahun 2008-2010". Skripsi. Depok : Fakultas Ekonomi Universitas Indonesia.

Wulantoro, A.F. 2011. "Analisis FaktorFaktor yang Mempengaruhi Ketetapan Waktu Publikasi Laporan Keuangan Perusahaan Manufaktur Go Public di Bursa Efek Jakarta". Skripsi. Semarang: Universitas Diponegoro.

Undang-Undang No.8 tahun 1995

www.bapepam.go.id, diakses tanggal 5 Maret 2016

www.idx.co.id, diakses tanggal 10 Maret 2016

www.Kbbi.web.id, diakses tanggal 6 Maret 2016

www.tipsserbaserbi.blogspot.co.id, diakses tanggal 6 April 2016 